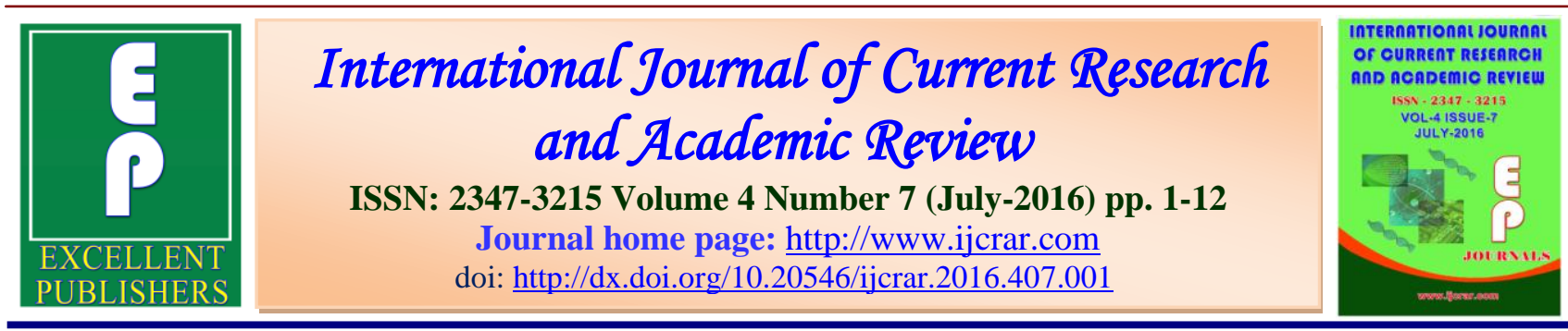

\title{
Determination of Optimal Vaccinal Dose of PPR Vaccine in Camel
}

\author{
S.M. Zeidan", A.T.El-Dakhly ${ }^{2}$, M.M. Youssef ${ }^{2}$, Abeer A.Tammam² and Amal A.Fotoah ${ }^{3}$ \\ ${ }^{1}$ Veterinary Serum and Vaccine Research Institute, Abbasia, Cairo, Egypt, Rinder Pest like \\ Disease Department, Egypt \\ ${ }^{2}$ Veterinary Serum and Vaccine Research Institute, Abbasia, Cairo, Egypt, Render Pest like \\ Disease Department, Egypt \\ ${ }^{3}$ Veterinary Serum and Vaccine Research Institute, Abbasia, Cairo, Egypt, Sheep pox \\ Department, Egypt
}

\section{*Corresponding author}

\begin{tabular}{|c|c|}
\hline KEYWORDS & A B S T R A C T \\
\hline $\begin{array}{l}\text { Optimal } \\
\text { vaccinal } \\
\text { dose, } \\
\text { PPR vaccine, } \\
\text { Camel. }\end{array}$ & $\begin{array}{l}\text { The present study was conducted to determine the optimal vaccinal dose of PPR } \\
\text { vaccine in camels. Three groups of camels were vaccinated by three different } \\
\text { doses of the vaccine; } 10^{2} \text { TCID } 50 \text { of PPR viruses, } 10^{3} \text { TCID } 50 \text { of PPR viruses and } \\
10^{5} \text { TCID50 of PPR viruses respectively. The immune response was evaluated by } \\
\text { SNT and competitive ELISA for the following } 6 \text { successive month post } \\
\text { vaccination. The group vaccinated with the } 10^{2} \text { TCID50 of PPR virus dose } \\
\text { showed the lowest immune response while the other two groups which were } \\
\text { vaccinated with } 10^{3} \text { TCID50 of PPR virus dose and } 10^{5} \text { TCID50 of PPR virus } \\
\text { dose showed mild to moderate immune response. The PPR vaccine was found to } \\
\text { be safe where there are no clinical symptoms after vaccination. It is concluded } \\
\text { that the optimal dose to vaccinate camel was } 10^{3} \text { TCID50 of PPR viruses to } \\
\text { protect the camel against infection with PPR virus. }\end{array}$ \\
\hline
\end{tabular}

\section{Introduction}

Peste des petits ruminants (PPR) disease, is caused by peste des petits ruminants virus (PPRV), this virus belongs to the genus Morbillivirus, family Paramyxoviridae (Woo et al., 2012). Peste des petits ruminants (PPR) is inflicting high losses to livestock so it is considered as a disease of major economic impact as reported by the World Animal Health Organization (OIE) particularly in the inter-tropical regions of Africa, in the Arabian Peninsula, the Middle
East and Asia (ElHag Ali and Taylor 1984; Taylor 1984; Shaila et al., 1989; Abu Elzein et al., 1990; Lefèvre and Diallo 1990; Nanda et al., 1996; Govindarajan et al., 1997; Wang et al., 2009).

Continuous outbreaks of PPR occur since more than 30 years affecting sheep and goats (El Hag Ali 1973; El Hag Ali and Taylor 1984; Saeed et al., 2010). It is worth mentioning that when the disease was first 
noted by El HagAli (El- Amin and Hassan 1998), it was thought to be rinderpest even though it was affecting mainly sheep and goats, but a small number of cattle and camel were also clinically affected. Serological surveys have demonstrated that camels are susceptible to the infection (Haroun et al., 2002).

Evidence of camels infection by PPRV has been recorded in many reports (Haroun et al., 2002; Shamaki 2002; Abraham et al., 2005; Khan et al., 2008; Chauhan et al., 2009; Albayrak and Gür 2010; Khalafalla et al., 2010; Kinne et al., 2010; Balamurugan et al., 2012). Clinical manifestation for PPR can be seen in per-acute, acute and sub-acute forms. However, PPR in sheep and goats is generally observed as an acute disease. The per-acute form of disease is often seen in kids infected at the age of 3 to 4 months and older during the time frame where there is any pre-existing maternal antibody levels wane. This per-acute form of disease has a short incubation period ( 2 days) with a rapid development of pyrexia where body temperature rising to $40-42^{\circ} \mathrm{C}$. Profound depression, congestion of mucous membranes, oculo-nasal discharge, dyspnea and profuse watery diarrhea leads to the death of infected animals within 4-5 days (Diallo, 2003; Munir et al., 2013).

PPR remains mainly the disease of sheep and goat with the latest more sensitive. However, it has been reported cases in India where sheep were more concerned than goats (Govindarajan et al., 1997). Cattle and pigs are susceptible to infection but do not contribute to the epidemiology as they are not capable to excrete virus while they produce specific antibodies against PPRV (Banyard et al., 2010).Case of PPR involving camels in Ethiopia was reported with the positive detection of PPRV antigens and nucleic acid but no virus isolation was obtained (Roger et al., 2000; Roger et al., 2001) In Sudan, during the period AugustOctober 2004, an outbreak occurred in a camel flock causing death with an average mortality rate of $7.4 \%$, It was confirmed as PPR with the isolation of the virus (Khalafalla et al., 2010; Saeed et al., 2010).

PPR in wild ungulates from variousspecies have been reported with death(Banyard et al., 2010 ; Kinne et al., 2010) .Infection with PPRV followed by the detection of specific antibodies and nucleic acids without any clinical signs has been also reported in Ivory-Coast (Couacy-Hymann et al., 2005).

The aim of the present work was designed to determine the optimal vaccinal dose of PPR vaccine in camels.

\section{Materials and Methods}

\section{Materials}

\section{Attenuated pest des petites ruminant's virus (PPRV)}

Attenuated strain of PPR virus (Nigerian Strain 75/1) (Diallo et al., 1989) was obtained from Rinder Pest Research Department, Veterinary Serum and Vaccine Research Institute, Abbasia Cairo, and was used for serological tests.

\section{PPR Vaccine}

A Vero cells adapted PPR vaccine prepared from Nigerian 75/1 strain supplied by Veterinary Serum and Vaccine Research Institute, Abassia, Cairo was used for vaccination of experimental camels. Titration of the used vaccine was done by micro titre plate according to Ferreira (1976) using Vero cell. The vaccine had a titer of 5 $\log 10 \mathrm{TC} \mathrm{ID}_{50} / \mathrm{ml}$. 
Polyethylene glycol 6000

It was obtained from Sigma Chemical Company, USA. It was used for preparation of purified soluble PPR antigen used in ELISA.

\section{Cellulose bags (Dialysis bags)}

These bags were obtained from Sigma Chemical Company, USA. It must be boiled in double distilled water for 5 minutes before use. It was used for PPR virus antigen preparation.

\section{PPR Antigen}

The supernatant fluid of infected Vero cell culture with PPR virus was collected at full cytopathic effect (CPE).The supernatant was concentrated using polyethylene glycol 6000 and cellulose bags. It was used as antigen in ELISA.

\section{Anti-equine conjugate}

It was used in competitive ELISA. In spite the titer of "Sigma" conjugate was previously determined; the conjugate should be freshly subjected to another titration before being used in competitive ELISA (Williams 1987).

\section{Equine hyper immune serum against PPR} virus

It was prepared at Veterinary Serum and Vaccine Research Institute, Abbasia, Cairo. It was used in competitive ELISA as control positive.

\section{Animals}

Eleven male camels of local breeds were screened using serum neutralizing test (SNT) and found to be free from Peste des petites ruminants antibodies. The camels were kept in clean stable; food and water were supplied ad libitum.

\section{Vaccination of experimental camels}

The experimental camels were divided randomly into four groups. The first group contains two camels. The other groups contain three camels.

Group-1: was kept unvaccinated as negative control.

Group-2: camels were vaccinated with $10^{2}$ TCID50 of PPR virus vaccine.

Group-3: camels were vaccinated with $10^{3}$ TCID50 of PPR virus vaccine.

Group-4: camels were vaccinated with $10^{5}$ TCID50 of PPR virus vaccines.

\section{Methods}

Evaluation of PPR antibody in sera of experimental camels

\section{Serum neutralization test (SNT)}

Both screening and quantitative SNT were performed by the micro technique as described by Ferreira (1976), in flat bottom tissue culture micro titer plates containing Vero cells. The SNT was applied on camel's sera before and on week intervals after vaccination with PPR vaccine for six months. The end point neutralizing antibody titer was expressed as the reciprocal of the final dilution of serum inhibiting the CPE of 100-200 TCID50 (Singh et al., 1967).

\section{Competitive enzyme linked immuno- sorbent assay (cELISA)}

Advice on the use and applicability of the Competitive enzyme-linked immunosorbent assay (cELISA) method is available from the OIE Reference Laboratories for PPR. 
The method described is available as a commercial kit. The competitive ELISA technique for the detection of antibodies of the Peste des petits ruminants (Anderson and McKay 1994; Libeau et al., 1995) have been developed and used in the field, and are commercially available.

\section{Results and Discussion}

In this study three types of vaccinal titer doses were used to vaccinate the experimental camels. These doses were; $10^{2}$ TCID50 of PPR virus vaccine this dose is the minimal dose can be used in sheep to give immune response, $10^{3}$ TCID50 of PPR virus vaccine this dose is used in vaccination of sheep in the field and the $10^{5}$ TCID50 of PPR virus vaccine (100X field dose of the PPR vaccine) according to OIE (2012) this dose is used to evaluate the safety of vaccine. These camels were clinically observed daily to detect post-vaccinal reaction, the vaccine considered safe when no abnormal clinical signs are observed in the vaccinated camels, in particular those which have received the highest dose.

\section{Serum neutralization test (SNT)}

The humeral immune responses were evaluated by SNT. The obtained results of SNT clarified that the camels which were vaccinated with the $10^{2}$ TCID50 of PPR virus vaccine exhibited immune response this immune response began from $1^{\text {st }}$ week post vaccination where the titre was $\leq 2$. This titer increased gradually and reached the peak in $4^{\text {th }}$ week post vaccination where the titre was 16. This titer persisted at this level up to $6^{\text {th }}$ month post vaccination as presented in table (1) and chart (1). The camels vaccinated with $10^{3}$ TCID50 of PPR virus vaccine showed immune response from the $1^{\text {st }}$ week where the titre was $\leq 2$ then increased regular until reached highest level in $2^{\text {nd }}$ month post vaccination where the titer was 64 up to $6^{\text {th }}$ month post vaccination as presented in table (1) and chart (1). The camels which vaccinated with $10^{5}$ TCID50 of PPR virus vaccine manifested immune response that was initiated from $1^{\text {st }}$ week post vaccination where the titre was $\leq 4$. This titer increased gradually and reached to peak on $2^{\text {nd }}$ month post vaccination where the titre was 64 . This titer persisted at this level up to $6^{\text {th }}$ month post vaccination as showed in table (1) and chart (1).

\section{cELISA (Competitive enzyme-linked immunosorbent assay)}

The data of competitive ELISA test was Compatible with the results of SNT. The competitive ELISA test showed that the humeral immune response was detectable in the 1 st week post vaccination where; the mean optical density of camels vaccinated with $10^{2}$ TCID50 of PPR virus vaccine was 0.088 in the first week post vaccination( $\mathrm{s} / \mathrm{p}$ ratio percentage was $19 \%$ ). These results are considered weak immune response. The highest mean optical density of these camels was $0.144(\mathrm{~s} / \mathrm{p}$ ratio percentage was $31.3 \%$ ) where was recorded $2^{\text {nd }}$ month post vaccination. These results are considered mild immune response as showed in tables (2 \& 3) and charts (2\&3).the immune response of this group persisted up to $6^{\text {th }}$ month post vaccination, where the optical density was 0.130 ( $\mathrm{s} / \mathrm{p}$ ratio percentage was $28.2 \%$ ). These results are considered mild immune response as showed in tables $(2 \&$ $3)$ and charts $(2 \& 3)$.

The mean optical density in case of camel vaccinated with $10^{3}$ TCID50 of PPR virus vaccine was 0.116 (the $s / p$ ratio percentage was $25.2 \%$ ). These results are considered mild immune response. While the highest optical density was $0.297 \quad(\mathrm{~s} / \mathrm{p}$ ratio 
percentage was $64.6 \%$ ) at $4^{\text {th }}$ week post vaccination. This results are considered high immune response as showed in tables $(2 \&$ $3)$ and charts (2\&3). The immune response of these group persisted up to $6^{\text {th }}$ month post vaccination, where the optical density was 0.232 (s/p ratio percentage was 50.4\%). These results are considered moderate immune response as showed in tables $(2 \&$ $3)$ and charts $(2 \& 3)$.

The mean optical density in case of camel vaccinated with $10^{5}$ TCID50 of PPR virus vaccine (100X field dose of the PPR vaccine in sheep) was $0.102(\mathrm{~s} / \mathrm{p}$ ratio percentage was $22.2 \%$ ) in the $1^{\text {st }}$ week post vaccination. This result is considered mild immune response. While the highest optical density was 0.266 ( $\mathrm{s} / \mathrm{p}$ ratio percentage $57.8 \%$ ) in the $4^{\text {th }}$ month post vaccination. this result is considered moderate immune response as showed in tables $(2 \& 3)$ and charts $(2 \& 3)$. The immune response of this group persisted up to $6^{\text {th }}$ month post vaccination, where the optical density was $0.261 \quad(\mathrm{~s} / \mathrm{p}$ ratio percentage was $56.7 \%$ ) These results are considered moderate immune response as showed in tables $(2 \& 3)$ and charts $(2 \& 3)$.

PPR disease was first described in Côte d'Ivoire (Gargadennec and Lalanne 1942), but it occurs in most African countries from North Africa to Tanzania, in nearly all Middle Eastern countries to Turkey, and is also widespread in countries from central Asia to South and South-East Asia (Banyard et al., 2010).Continuous outbreaks of PPR occur since more than 30 years in these countries affecting sheep and goats (Saeed et $a l ., 2010)$. It is worth mentioning that when the disease was first noted by El Hag Ali (El Amin and Hassan 1998) it was thought to be rinder pest even though it was affecting mainly sheep and goats, but a small number of cattle were also clinically affected. Serological surveys have demonstrated that camels are susceptible to the infection (Haroun et al., 2002) and in some instance may express a serious illness (respiratory distress) and mortality.

Abdelmelik et al., (2010) mentioned that in mid-August 2004, an outbreak of a previously unknown fatal disease of camels was reported to Kassala State Veterinary Authorities. Clinically, the disease was characterized by sudden death of apparently healthy animals and yellowish and later bloody diarrhea and abortion. Death was always sudden and proceeded with colic and difficulty in respiration. Mortality rate ranged between $0 \%$ and 50\%. All age, sex and breed groups were affected but more than $50 \%$ of deaths were reported in adult animals in comparison to calves and young camels. The serological tests gave positive results for peste des petits ruminants' virus (PPRV).

Until recently the Tissue Culture Rinder pest Vaccine was used successfully for the induction of cross protection against PPR owing to the antigenic similarities between the two viruses (Diallo et al., 2007).Camels are considered susceptible to PPR but this is still to be clarified by experimental infections. It has been shown that camels can seroconvert to the PPRV (Roger et al., 2001). Recent observations in Sudan suggest that camels could be affected by PPR, as they can show clinical expression of the disease and positive results were detected by serological tests, including reverse transcription polymerase chain reaction (RTPCR), and PPRV was isolated in cell culture (Khalafalla et al., 2010; Kwiatek et al., 2011). 
Int.J.Curr.Res.Aca.Rev.2016; 4(7): 1-12

Table.1 Mean PPR serum neutralizing antibody titer in vaccinated camels by PPR vaccine

\begin{tabular}{|c|c|c|c|c|c|c|c|c|c|c|}
\hline \multicolumn{10}{|c|}{ Mean PPR serum antibody titer /time post vaccination } \\
\hline $\begin{array}{c}\text { Animals } \\
\text { Group }\end{array}$ & $\begin{array}{c}0 \\
\text { DPV }\end{array}$ & $\begin{array}{c}1^{\text {st }} \\
\text { WPV }\end{array}$ & $\begin{array}{c}2^{\text {nd }} \\
\text { WPV }\end{array}$ & $\begin{array}{c}3^{\text {rd }} \\
\text { WPV }\end{array}$ & $\begin{array}{c}4^{\text {th }} \\
\text { WPV }\end{array}$ & $\begin{array}{c}2^{\text {nd }} \\
\text { MPV }\end{array}$ & $\begin{array}{c}3^{\text {rd }} \\
\text { MPV }\end{array}$ & $\begin{array}{c}4 \text { th } \\
\text { MPV }\end{array}$ & $\begin{array}{c}5^{\text {th }} \\
\text { MPV }\end{array}$ & $\begin{array}{c}6^{\text {th }} \\
\text { MPV }\end{array}$ \\
\hline ( G1 ) & 0 & 0 & 0 & 0 & 0 & 0 & 0 & 0 & 0 & 0 \\
\hline ( G2 ) & 0 & $\leq 2^{*}$ & 4 & 8 & 16 & 16 & 16 & 16 & 16 & 16 \\
\hline ( G3 ) & 0 & $\leq 2$ & 8 & 16 & 32 & 64 & 64 & 64 & 64 & 64 \\
\hline ( G4 ) & 0 & $\leq 4$ & 8 & 16 & 32 & 64 & 64 & 64 & 64 & 64 \\
\hline
\end{tabular}

*Antibodies titer $=$ the reciprocal of serum dilution which neutralize and inhibit the CPE

Of100-200 TCID50 OF PPR VIRUS.

$\mathrm{G} 1=$ control negative

$\mathrm{G} 2=$ was vaccinated with $10^{2}$ TCID50 of PPR virus vaccine

G3 = was vaccinated with $10^{3}$ TCID50 of PPR virus vaccine

G4= was vaccinated with $10^{5}$ TCID50 ofPPR virus vaccine

D P V = Days Post vaccinationW P V = week post vaccinationM P V= Month Post vaccination

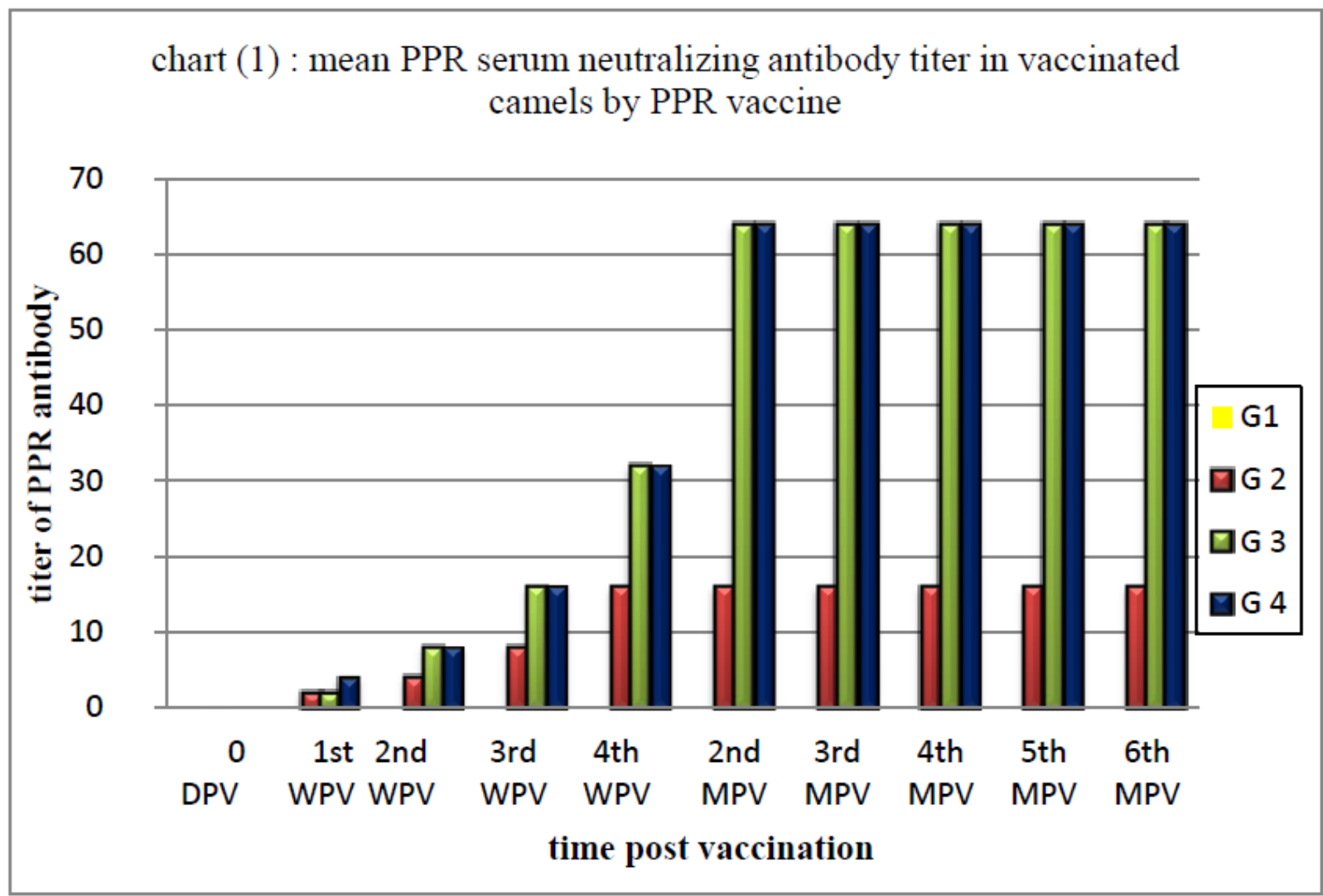

*Antibodies titer $=$ the reciprocal of serum dilution which neutralize and inhibit the CPE of 100-200 TCID50 OF PPR VIRUS.

$\mathrm{G} 1=$ control negative

$\mathrm{G} 2=$ was vaccinated with $10^{2}$ TCID50 of PPR virus vaccine

$\mathrm{G} 3=$ was vaccinated with $10^{3}$ TCID50 of PPR virus vaccine

G4= was vaccinated with $10^{5}$ TCID50 of PPR virus vaccine

D P V = Days Post vaccinationWPV = week post vaccination

M P V = Month Post vaccination 
Int.J.Curr.Res.Aca.Rev.2016; 4(7): 1-12

Table.2 Mean optical density of competitive ELISA in vaccinated camels by PPR vaccine

\begin{tabular}{|c|c|c|c|c|c|c|c|c|c|}
\hline \multicolumn{10}{|c|}{ time post vaccination } \\
\hline Animals & $1^{\mathrm{st}}$ & $2^{\text {nd }}$ & $3^{\text {rd }}$ & $4^{\text {th }}$ & $2^{\text {nd }}$ & $3^{\text {rd }}$ & 4 th & $5^{\text {th }}$ & $6^{\text {th }}$ \\
\hline Group & WPV* & WPV & WPV & WPV & MPV*** & MPV & MPV & MPV & MPV \\
\hline ( G1) & 0.029 & 0.017 & 0.022 & 0.015 & 0.019 & 0.024 & 0.017 & 0.014 & 0.027 \\
\hline ( G2 ) & 0.088 & 0.082 & 0.138 & 0.104 & 0.144 & 0.124 & 0.130 & 0.134 & 0.130 \\
\hline ( G3 ) & 0.116 & 0.179 & 0.202 & 0.297 & 0.231 & 0.225 & 0.235 & 0.230 & 0.232 \\
\hline ( G4 ) & 0.102 & 0.114 & 0.158 & 0.234 & 0.240 & 0.262 & 0.266 & 0.252 & 0,261 \\
\hline
\end{tabular}

G1= control negative

$\mathrm{G} 2=$ was vaccinated with $10^{2}$ TCID50 of PPR virus vaccine

$\mathrm{G} 3=$ was vaccinated with $10^{3}$ TCID50 of PPR virus vaccine

$\mathrm{G} 4=$ was vaccinated with $10^{5}$ TCID50 of PPR virus vaccine

*WPV $=$ week post vaccination

**M P V = Month Post vaccination

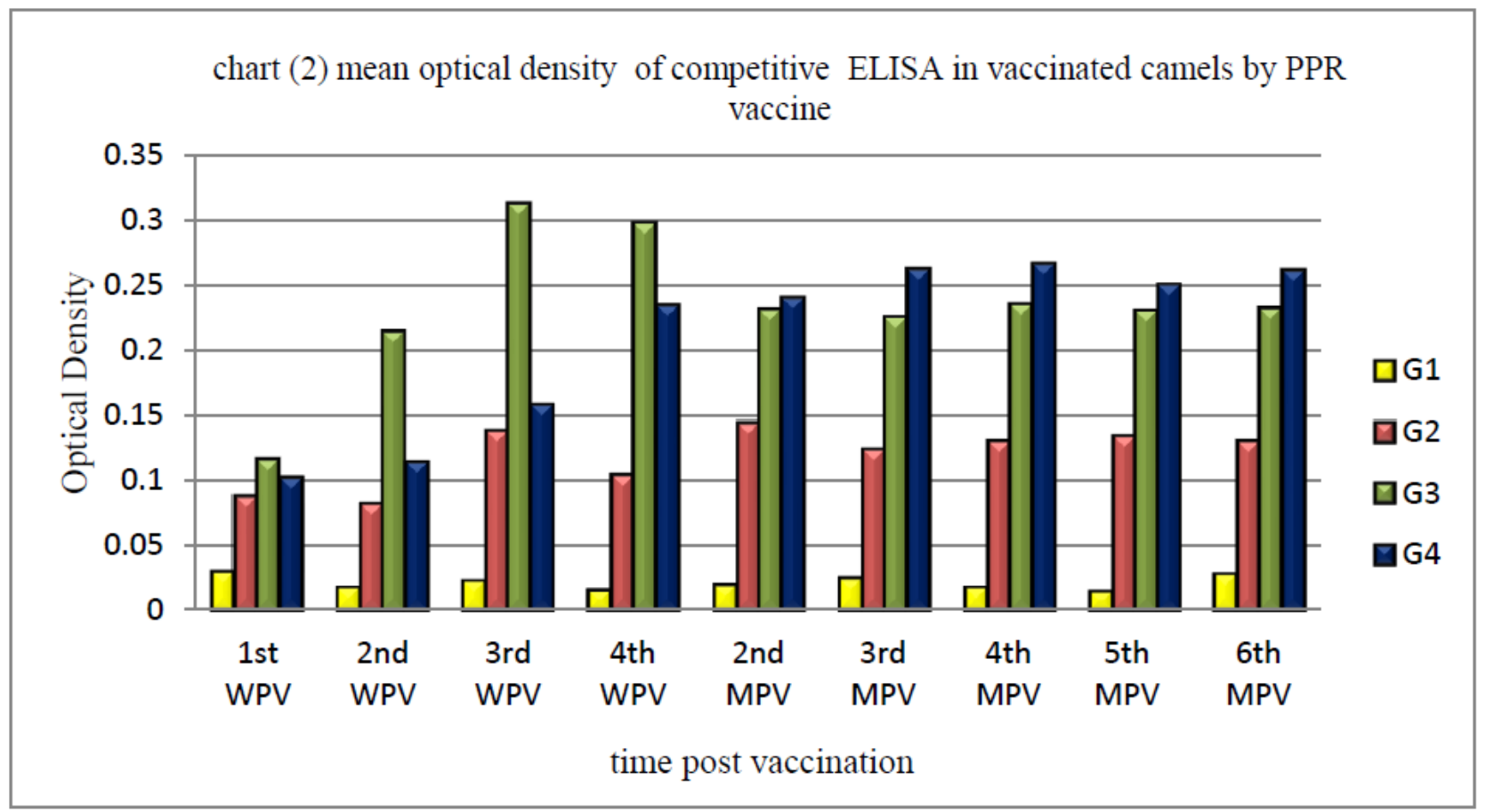

G1 = control negative

$\mathrm{G} 2=$ was vaccinated with $10^{2}$ TCID50 of PPR virus vaccine

$\mathrm{G} 3=$ was vaccinated with $10^{3}$ TCID50 of PPR virus vaccine

G4= was vaccinated with $10^{5}$ TCID50 of PPR virus vaccine

W P V = week Post vaccination

M P V = month Post vaccination 
Int.J.Curr.Res.Aca.Rev.2016; 4(7): 1-12

Table.3 Mean PPR -competitive ELISA S/P ratio percentage in vaccinated camels

\begin{tabular}{|c|c|c|c|c|c|c|c|c|c|}
\hline \multicolumn{10}{|c|}{ Time post vaccination } \\
\hline $\begin{array}{c}\text { Animals } \\
\text { Group }\end{array}$ & $\begin{array}{c}1^{\text {st }} \\
\text { WPV }\end{array}$ & $\begin{array}{c}2^{\text {nd }} \\
\text { WPV }\end{array}$ & $\begin{array}{c}3^{\text {rd }} \\
\text { WPV }\end{array}$ & $\begin{array}{c}4^{\text {th }} \\
\text { WPV }\end{array}$ & $\begin{array}{c}2^{\text {nd }} \\
\text { MPV }\end{array}$ & $\begin{array}{c}3^{\text {rd }} \\
\text { MPV }\end{array}$ & $\begin{array}{c}4 \text { th } \\
\text { MPV }\end{array}$ & $\begin{array}{c}5^{\text {th }} \\
\text { MPV }\end{array}$ & $\begin{array}{c}6^{\text {th }} \\
\text { MPV }\end{array}$ \\
\hline ( G1 ) & $6 \%$ & $3.7 \%$ & $4.8 \%$ & $3.3 \%$ & $4.1 \%$ & $5.2 \%$ & $3.7 \%$ & $3 \%$ & $5.9 \%$ \\
\hline ( G2 ) & $19 \%$ & $17.8 \%$ & $30 \%$ & $22.6 \%$ & $31.3 \%$ & $27 \%$ & $28.3 \%$ & 29.1 & $28.2 \%$ \\
\hline ( G3 ) & $25.2 \%$ & $38.9 \%$ & $43.9 \%$ & $64.6 \%$ & $50.2 \%$ & $48.9 \%$ & $51.1 \%$ & $50 \%$ & $50.4 \%$ \\
\hline ( G4 ) & $22.2 \%$ & $24.8 \%$ & $34.5 \%$ & $50.9 \%$ & $52.2 \%$ & $57 \%$ & $57.8 \%$ & $54.8 \%$ & $56.7 \%$ \\
\hline
\end{tabular}

Competitive ELISA S/P ratio percentage where; less than $20 \%$ weak immuneresponse, $20 \%-40 \%$ mild immuneresponse, $40 \%-60 \%$ moderate immuneresponse, more than $60 \%$ high immuneresponse.

$\mathrm{G} 1=$ control negative

$\mathrm{G} 2=$ was vaccinated with $10^{2}$ TCID50 of PPR virus vaccine

G3 = was vaccinated with $10^{3}$ TCID50 of PPR virus vaccine

G4= was vaccinated with $10^{5}$ TCID50 of PPR virus vaccine

W P V = week Post vaccination

M P V = Month Post vaccination

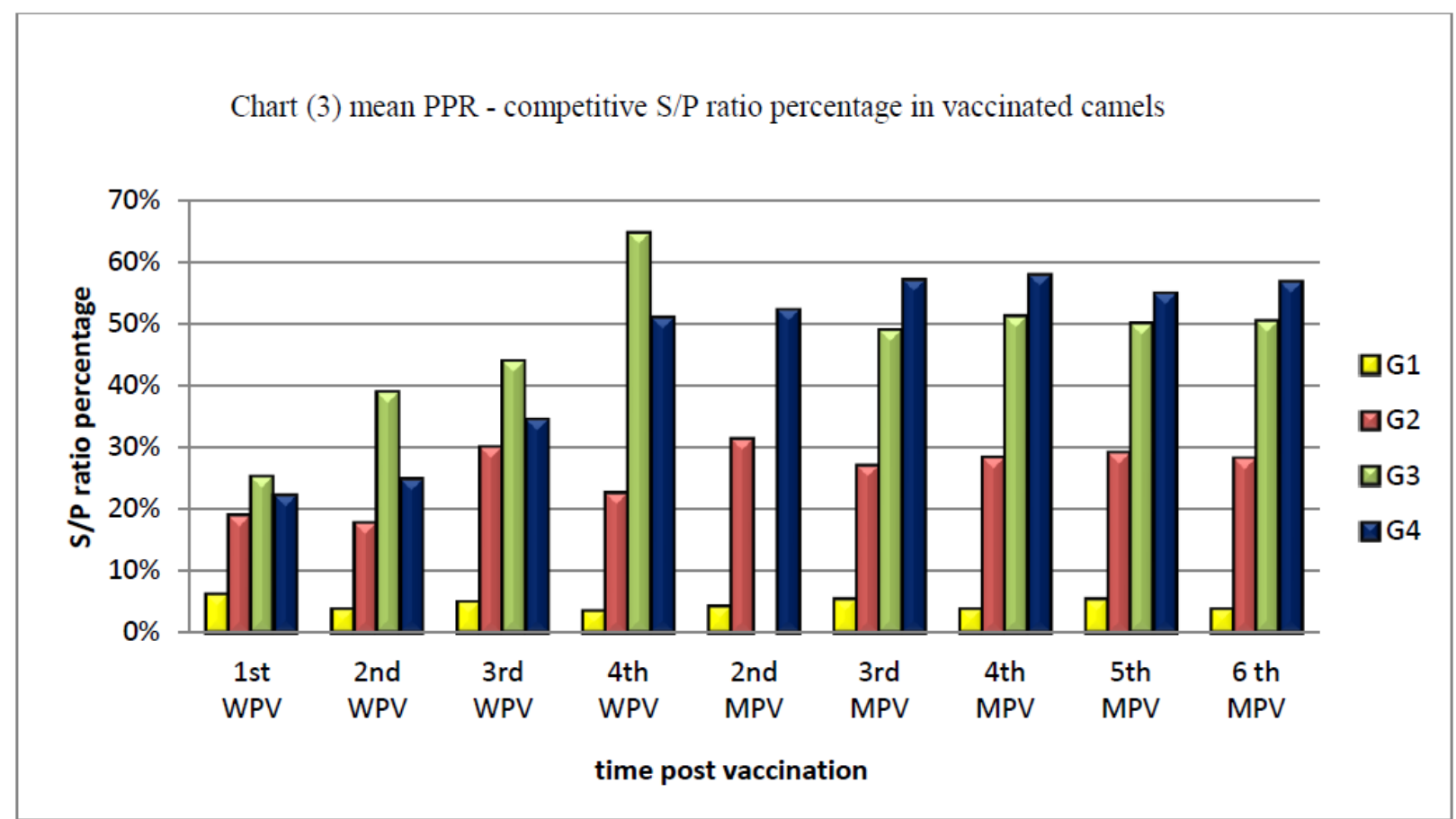

Competitive ELISA S/P ratio percentage where; less than $20 \%$ weak immuneresponse, 20\%-40\%mild immuneresponse, $40 \%-60 \%$ moderate immuneresponse, more than $60 \%$ high immuneresponse.

$\mathrm{G} 1=$ control negative

$\mathrm{G} 2=$ was vaccinated with $10^{2}$ TCID50 of PPR virus vaccine

$\mathrm{G} 3=$ was vaccinated with $10^{3}$ TCID50 of PPR virus vaccine

G4= was vaccinated with $10^{\mathbf{5}}$ TCID50 of PPR virus vaccine

W P V = week Post vaccination

M P V = Month Post vaccination

Through the foregoing we had vaccinated the three groups of experimental camel
(G2\& G3 and G4) with three different doses of vaccine. The G2 which vaccinated with 
Int.J.Curr.Res.Aca.Rev.2016; 4(7): 1-12

$10^{2}$ TCID50 of PPR virus vaccine showed low immuno response where the titer of antibodyby SNT was 16 up to the end $6^{\text {th }}$ month of vaccination (as shown in table 1 and chart 1) and these result confirmed by competitive ELSA where $\mathrm{s} / \mathrm{p}$ ratio percentage was $28.2 \%$ in the end $6^{\text {th }}$ month of experiment (mild immuneresponse) (as shown in table 3 and chart 3 ). These result may attributed to low titer power of injected dose from the vaccine. The other two group (G3 and G4) which vaccinated with $10^{3}$ TCID50 of PPR virus vaccine and $10^{5}$ TCID50 of PPR virus vaccine showed moderate immuno response where the titer of antibody by SNT was64 up to the end 6th month of vaccination (as shown in table 1 and chart 1) and these result confirmed by competitive ELSA where $\mathrm{s} / \mathrm{p}$ ratio percentage was in range $56 \%$ in the end 6 th month of experiment (moderate immuneresponse) (as shown in table 3 and chart 3 ). These result may attributed to higher titer power of injected dose from the vaccinethan titerpower of $10^{2}$ TCID50 of PPR virus vaccine. These camels were clinically observed daily to detect postvaccinal reaction, the vaccine considered safe where there is no abnormal clinical signs were observed in the vaccinated camels, in particular those which have received the highest dose.

These results agree with European Food Safety Authority(2015) where; stated that there are two trials in Morocco showed moderate immunological responses tested by serum neutralization and enzyme-linked immunosorbent assay (ELISA)in camels vaccinated with Nigeria 75/1strain.

There is a need for more research in this domain to elucidate the role of camels in the epidemiology of PPR, in particular to find out if this species can excrete the virus and From the previous information, we can use $10^{3}$ TCID50 of PPR virus vaccine to vaccinate camels before outbreak of PPR disease.

\section{References}

Abdelmelik, I., Khalafalla., Intisar, K., Saeed., Yahia, H., Ali., Magdi, B., Abdurrahman, Olivier, Kwiatek., Geneviève, Libeau, Ali, Abu, Obeidaand Zakia Abbas. 2010. An outbreak of peste des petits ruminants (PPR) in camels in the Sudan. Acta Tropica, 116: 161-165.

Abraham, G., Sintayehu, A., Libeau, G., Albina, E., Roger, F., Laekemariam, Y., Abayneh, D and Awoke, K.M. 2005. Antibody seroprevalences against peste des petits ruminants (PPR) virus in camels, cattle, goats and sheep in Ethiopia. Preventive Vet. Med., 70: 51-57.

Abu Elzein, E.M., Hassanien, M.M., AlAfaleq, A.I., Abd Elhadi, M.A and Housawi, F.M. 1990. Isolation of peste des petits ruminants from goats in Saudi Arabia. Vet. Rec., 127(12): 309-310.

Albayrak, H., Gür, S. 2010. A serologic investigation for peste des petits ruminant's infection in sheep, cattle, and camels (Camelus dromedarius) in Aydin province, West Anatolia. Trop. Animal Health and Production, 42: 151-153.

Anderson, J., McKay, J.A. 1994. The Detection of Antibodies against Peste des Petits Ruminants Virus in Cattle, Sheep and Goats and the Possible Implications to Rinderpest Control Programmes. Epidemiol. Infect. 112(1): 225-231.

Balamurugan, V., Krishnamoorthy, P., Veeregowda, B.M., Sen, A., Rajak, K.K., Bhanuprakash, V., Gajendragad, M.K and Prabhudas, K. 2012. 
Int.J.Curr.Res.Aca.Rev.2016; 4(7): 1-12

Seroprevalence of peste des petits ruminants in cattle and buffaloes from sourthern peninsular India. Trop. Animal Health and Production, 44: $301-306$.

Banyard, A.C., Parida, S., Batten, C., Oura, C., Kwiatek, O., Libeau, G. 2010. Global distribution of peste des ruminant's virus and prospects for improved diagnosis and control. $J$. Gen. Virol., 91: 2885 - 2897.

Chauhan, H.C., Chandel, B.S., Kher, H.N., Dadawala, A.I. and Agrawal, S.M. 2009. Peste des petits ruminant's virus infection in animals. Vet. World, 2: 150-155.

Couacy-Hymann, E., Bodjo, S.C., Danho, T., Libeau, G., Diallo, A. 2005. Surveillance of wildlife as a tool for monitoring rinderpest and peste des petits ruminants in West Africa. Rev. Sci. tech. Off. int. Epiz., 24: 869-877.

Diallo, A. 2003. Peste des petits ruminants. In Principales maladies infectieuses ET parasitizes du bétail, Europe et regions chaudes, Volume 1. Lefèvre P.C., Blancou J. ET R. Chermette (Eds). Editions TEC \& DOC, Paris: 307-322.

Diallo, A., Barrett, T., Barbron, M., Shaila, M.S and Taylor, W.P. 1989. "Differentiation of rinderpest and peste des petits ruminant's viruses using specific cDNA clones" J. Virol. Methods, 23: 127-136.

Diallo, A., Minet, C., Le Goff C., Berhe, G., Albina, E., Libeau, G. and Barrett T. (2007) The Threat of Peste des Petits Ruminants: Progress in Vaccine Development for Disease Control. Vaccine, 25: 55915597.http://dx.doi.org/10.1016/j.vacci ne.2007.02.013

El- Amin, M.A.G and Hassan, A.M. 1998. The seromonitoring of rinderpest throughout Africa, phase III results for
1998. IAEA, VIENNA, Food and Agriculture Organization/ International Atomic Energy Agency. El Hag Ali, B. 1973. A natural outbreak of rinderpest involving sheep, goats and cattle in Sudan. Bull. Epizootic dis. Afr., 12: 421-428.

El Hag Ali, B., Taylor, W.P. 1984. Isolation of peste des petits ruminant's virus from Sudan. Res. Vet. Sci., 36: 1-4.

European Food Safety Authority (EFSA), Parma, Italy. 2015. Scientific Opinion on peste des petits ruminants, EFSA Panel on Animal Health and Welfare (AHAW). EFSA J., 13(1):3985. www.efsa.europa.eu/efsajournal

Ferreira, M.E. 1976. Pruba de micro neutralization proestudose de antiricrupos de la fiebre aftose. Centropano américano de F. Ubrea afrosa, 211: 17-27.

Gargadennec, L., Lalanne, A. 1942. La peste des petits ruminants. Bull. Serv. Zoo. A.O.F., 5: 15-21.

Govindarajan, R., Koteeswaran, A., Venugopalan, A.T., Shyam, G., Shaouna, S., Shaila, M.S andRamachandran, S. 1997. Isolation of pestes des petits ruminant's virus from an outbreak in Indian buffalo (Bubalus bubalis). Vet. Rec., 141(22): 573-574.

Haroun, M., Hajer, I., Mukhtar, M and Ali, B.E. 2002. Detection of antibodiesagainst Peste des Petits Ruminants virus in sera of cattle, camels, sheep and goats in Sudan. Vet. Res. Communications, 26: 537-541.

Khalafalla, A.I., Saeed, I.K., Ali, Y.H., Abdurraham, M.B., Kwiatek, O., Libeau, G., Obeida, A.A and Abbas, Z 2010. An outbreak of Peste des Petits Ruminants (PPR) in camels in the Sudan. Acta Tropica, 116: 161-165.

Khan, H.A., Siddique, M., Rahman, S., Abubakar, M and Ashraf, M. 2008. 
The detection of antibody against Peste des Petits Ruminants virus in sheep, goats, cattle and buffaloes. Trop. Ani. Health Production, 40: 521-527.

Kinne, J., Kreutzer, R., Kreutzer, M., Wernery, U and Wohlsein, P. 2010. Peste des Petits Ruminants in Arabian wildlife. Epidemiol. Infect., 138: 1211-1214.

Kwiatek, O., Ali, Y.H., Saeed, I.K., Khalafalla, AI., Mohamed, O.I., Obeida, A.A., Abdelrahman, M.B., Osman, H.M., Taha, K.M., Abbas, Z., El Harrak, M., Lhor, Y., Diallo, A., Lancelot, R., Albina, E and Libeau, G. 2011. Asian lineage of peste des petits ruminants virus, Africa. Emerging Infect. Dis., 17: 1223-1231.

Lefèvre, P.C., Diallo, A. 1990. Peste des petits ruminants. Rev. Sci. Technol., 9(4): 935-981.

Libeau, G., Prehaud, C., Lancelot, R., Colas, F., Guerre, L., Bishop, D.H.L and Diallo, A. 1995. Development of a competitive Elisa for detecting antibodies to the peste des petits ruminants virus using a recombinant nucleoprotein. Res. Vet. Sci., 58: 5055.

Munir, M., Zohari, S., Berg, M. 2013. Pathophysiology and clinical assessment of peste des petits ruminant's virus. In M. Munir, S. Zohari \& M. Berg (Eds.), Molecular biology and pathogenesis of Peste des Petits Ruminants virus (pp. 33-48). New York: Springer

Nanda, Y.P., Chatterjee, A., Purohit, A.K., Diallo, A., Innui, K., Sharma, R.N., Libeau,G., Thevasagayam, J.A., Brüning, A., Kitching, R.P., Anderson, J., Barrett, T and Taylor, W.P. 1996. The isolation of peste des petits ruminant's virus from northern India. Vet. Microbiol., 51(3-4): 207-216.
OIE. 2012. World Organization for Animal Health, Office International des Epizooties. Peste des petits ruminants Chapter 2.7.11.

Roger, F., Yigezu, L.M., Hurard, C., Libeau, G., Mebratu, G.y., Diallo, A and Faye, B. 2000. Investigations on a new pathological condition of camels in Ethiopia. J. Camel. Pract. Res, 7: 163165.

Roger, F., Guerre Yesus, M., Libeau, G., Diallo, A., Yigezu, L.M and Yilma, T. 2001. Detection of antibodies ofrinderpest and peste des petits ruminants viruses(Paramyxoviridae, Morbillivirus) during a new epizootic disease inEthiopian camels (Camelus dromedarius). Rev. Med. Vet., 152: 265-268.

Saeed, I.K., Ali, Y.H., Khalafalla, A.I. and Rahman-Mahasin, E.A. 2010. Current situation of peste des petits ruminants (PPR) in the Sudan. Trop. Anim. Health Prod., 42(1): 89-93.

Shaila, M.S., Purushothaman, V., Bhavasar, D., Venugopal, K., Venkatesan, R.A (1989). Peste des petits ruminants of sheep in India. Vet. Rec., 125(24): 602.

Shamaki, D. 2002. Some aspects of serological and molecular epidemiology of Peste des Petits Ruminants (PPR) in Nigeria. PhD Thesis, University of Ibadan.

Singh, K.V., Osman, O.A., Ivon, F.E and Thanaa, I.B. 1967. Colostral transfer of RP neutralizing antibody to off offspring vaccinated dam. Canad J. Comp. Med.Vet. Sci., 31(11) archive.

Taylor, W.P. 1984. The distribution and epidemiology of peste des petits ruminants. Prev. Vet. Med., 2: 157166.

Wang, Z., Bao, J., Wu, X., Liu, Y., Li, L., Liu, C., Suo, L., Xie, Z., Zhao, W., Zhang, W., Yang, N., Li, J., Wang, S. and Wang, J. 2009. Peste des petits 
ruminant's virus in Tibet. China Emerg. Infect. Dis., 15(2): 299-301.

Williams, R. 1987. ELISA technique for diagnosis of African horse sickness virus. J. Vet. Diag. Invest., 11(2): 911.

Woo, P.C., Lau, S.K., Wong, B.H., Fan, R.Y., Wong, A.Y., Zhang, A.J., Wu, Y., Choi, G.K., Li, K.S., Hui, J.,Wang, M., Zheng, B.J., Chan, K.H and
Yuen, K.Y. 2012. Feline Morbillivirus, a previously undescribed paramyxovirus associated with tubulointerstitial nephritis in domestic cats. Proceedings of the National Academy of Science, 109: 5435-40.

\section{How to cite this article:}

Zeidan, S.M., A.T.El-Dakhly, M.M. Youssef, Abeer A.Tammam and Amal A.Fotoah. 2016. Determination of optimal vaccinal dose of PPR vaccine in Camel. Int.J.Curr.Res.Aca.Rev.4(7): 1-12. doi: http://dx.doi.org/10.20546/ijcrar.2016.407.001 